\title{
Chile - Price Band System and Safeguard Measures Relating to Certain Agricultural Products*
}

\author{
BY
}

\author{
KYLE BAGWELL \\ Columbia University \\ AND \\ ALAN O. SYKES \\ University of Chicago
}

\section{Introduction}

This study addresses the dispute brought to the World Trade Organization (WTO) by Argentina concerning certain Chilean measures affecting the importation of wheat, wheat flour, oil seeds, edible vegetable oils and sugar. The complaint by Argentina challenged two types of policies - a "price band system" that was applicable to four of those product categories, and safeguards measures that were applicable to three of them. The WTO panel ruled in favor of Argentina on both sets of measures. ${ }^{1}$ It found that the price band system violated Article IV of the Agriculture Agreement and Article II of GATT 1994. The safeguards measures, according to the panel, violated various provisions of the Safeguards Agreement, as well as Article XIX of GATT 1994. Chile elected not to appeal the panel ruling regarding the safeguards measures, but did appeal the adverse finding as to the price band system. The Appellate Body subsequently affirmed in substantial part the finding that the price band system violated Article 4 of the Agriculture

\footnotetext{
* We wish to thank Alberto Martin for valuable assistance, and to thank the other reporters and conference participants of the American Law Institute for many valuable ideas and suggestions.

${ }^{1}$ Chile - Price Band System and Safeguard Measures Relating to Certain Agricultural Products, Report of the Panel, WT/DS207/R (May 3, 2002) (hereafter Panel Rep.).
} 
Agreement, but reversed the finding of a violation under Article II of GATT $1994 .{ }^{2}$ Chile has since indicated an intention to comply with the ruling, and an arbitration pursuant to Article 21.3 of the DSU has determined that the reasonable period of time for compliance will expire on December 23, 2003.

Because the issues raised by Argentina regarding the safeguards measures have for the most part surfaced in other cases that deal with them in greater detail, and because Chile did not appeal the panel's findings on these issues, we will not address them here. Instead, we focus on the issues before the Appellate Body, devoting careful attention to the treatment of the price band system, and very brief attention to some general procedural issues.

The price band issue has reasonably broad significance for three reasons. First, price band systems, which aim to reduce the volatility of agricultural prices, are maintained by a number of WTO members (some also maintain seasonal tariffs, which might also be subject to challenge in the future). Indeed, the complaining nation in the case Argentina - maintains a price band system of its own for sugar imports. ${ }^{3}$ Second, a resolution of the question as to the legality of the price band system implicates the broader question of what agricultural measures were required to be "tariffied" under the Uruguay Round Agreements. As shall be seen below, Chile's ultimate defeat before the Appellate Body rested on the proposition that its price band system should have been converted into an "ordinary customs duty" at the end of the Uruguay Round. Third, and perhaps most interesting from an economic perspective, the case raises the question of what constraints apply to WTO Members that wish to vary their tariff rates over time below their bound levels. The Chilean price band system, as amended, ensured that any additional tariffs required by the price band would not cause the total tariff on any imported good to exceed the applicable tariff binding. Nevertheless, the system was condemned because the way in which it was administered made it sufficiently "similar" to measures that had been required to be "tariffied."

We lay out the legal issues and arguments in Section 2. Section 3 offers a critical analysis of the case from a law and economics perspective.

${ }^{2}$ Chile - Price Band System and Safeguard Measures Relating to Certain Agricultural Products, Report of the Appellate Body, AB-2002-2, WT/DS207/R (September 22, 2002) (hereafter AB Rep.).

${ }^{3}$ See Raj Bhala and David Gantz, WTO Case Review 2002, 20 Ariz. J. Int'l L. 143, 255 (2003). 


\section{Factual and Legal Issues}

\subsection{Description of the price band system}

The stated objective of the price band system was to "ensure a reasonable margin of fluctuation of domestic wheat, oil-seed, edible vegetable oil and sugar prices in relation to the international prices for such products." ${ }^{\prime 4}$ To this end, Chile employed a somewhat convoluted procedure.

The price band itself was established annually. Depending on the product, either five or ten years of data would be gathered on the monthly average prices of the product in the "most relevant markets" abroad. ${ }^{5}$ The edible vegetable oil price was apparently FOB Chicago Exchange, for example, while the wheat price was that of Hard Red Winter No. 2 FOB Gulf (Kansas Exchange). ${ }^{6}$ These prices were adjusted for inflation, and then arrayed in ascending order. The highest 25 percent and lowest 25 percent of these average prices ( 35 percent in the case of sugar) were then discarded. From the remaining prices, the highest and the lowest for each product would be selected. Ordinary tariffs, transport, insurance and related costs were then added to these high and low prices, thus yielding a delivered price to Chile. These adjusted prices then became the annual price band for each product.

The process of establishing the price band was not transparent. There was apparently no published information indicating which foreign markets were the "relevant" ones or how they were selected. Likewise, no published information specified exactly which product prices would be used (soybean oil prices or sunflowerseed oil prices in the case of edible vegetable oils, for example), and no published source provided the basis for the various adjustments used to convert from FOB to delivered prices. ${ }^{7}$

Once the price band was established, it remained to compute the applicable duty on each shipment at the border. Interestingly, the actual transaction prices of products entering Chile were not employed, Rather, for each product, Chile would select a weekly "reference price." That price would be the lowest FOB price observed in any foreign "market of concern" during the week in which the shipment left its home market. Once again, it was not clear how the "markets of concern" were selected, or

\footnotetext{
AB Rep. 911.

AB Rep. n. 15.

$\mathrm{AB} \Upsilon 18$.

${ }^{7}$ See Panel Rep $\llbracket 7.44$.
} 
precisely which prices in those markets would be used. ${ }^{8}$ The reference price was not adjusted for the costs of delivering the product to Chile from the market in question.

To determine the total tariff liability for each import shipment under this system, Chile would first apply its ordinary ad valorem tariff. In addition, Chile would ascertain when the shipment left its home market, and identify the reference price for that week for the product category in question. It would compare this reference price to the annual price band. If the reference price fell below the lower threshold of the price band, an additional specific duty would be applied to the shipment in an amount equal to the difference between the reference price and the low threshold price. By contrast, if the reference price fell outside the upper threshold of the price band, the importer would receive a rebate equal to the difference between the reference price and the upper threshold price. Finally, whenever the reference price fell within the price band, only the ordinary ad valorem duty would be collected, regardless of the actual transaction price of the shipment in question.

To illustrate, imagine a shipment of one ton of wheat arriving in Chile during the third week of September, and assume that its delivered price for tariff purposes is $\$ 100$. Assume further that Chile's ad valorem tariff on wheat is 10 percent. The shipment originated in the United States during the first week of September. Assume further that the annual price band for wheat is $\$ 130-\$ 180$ per ton. Lastly, assume that the reference price for wheat during the first week of September was $\$ 90$ per ton. Then, total tariff liability on the shipment would equal $\$ 50$ : $\$ 10$ resulting from the 10 percent ad valorem tariff, and another $\$ 40$ resulting from the difference between the lower threshold of the price band (\$130) and the reference price (\$90). If the shipment had instead had a delivered price of $\$ 200$ and the pertinent reference price had been $\$ 190$, tariff liability would have been only $\$ 10$ : $\$ 20$ based on the ad valorem rate, less a $\$ 10$ rebate due to the fact that the reference price exceeded the upper threshold of the price band by $\$ 10$.

It is plain from the design of the system that it will tend to produce positive additional tariffs (above the ad valorem duty) on average (that is, the additional duties due to reference prices below the price band will not on average be offset by rebates due to reference prices above the price band). One reason is that the reference prices are FOB foreign markets, while the price band is based on delivered prices to Chile. Further, the reference price is always the lowest FOB price observed during the week in

${ }^{8}$ AB Rep. $\Upsilon \Upsilon 23-25$. 
question in some foreign market of relevance. The average duty can be further inflated (or not) depending on precisely which foreign markets are used as the basis for the reference price, and which product prices are used. Finally, the rebates would never exceed the ordinary ad valorem tariff (there was never a "negative" duty), but the additional duties could well exceed it.

The reader may wonder how the total duty computed under this system related to Chile's tariff bindings. Chile had bound its tariffs under Article II of GATT 1994 at 31.5 percent for all of the products at issue in the price band system. In practice, however, Chile applied only a 7 or 8 percent tariff rate ${ }^{9}$ to these products. Thus, as long as the additional duties under the price band system did not exceed each shipment's delivered value for tariff purposes multiplied by 31.5 percent less the applied ad valorem rate, the total tariff remained within the binding. But the total duty had on occasion exceeded the binding. ${ }^{10}$ After the dispute began, however, Chile enacted an amendment to its price band system providing that in no event should the total duty applied to any product covered by the price band system exceed 31.5 percent of its value.

\subsection{Argentina's challenge and Chile's response}

\subsubsection{Article II of GATT 1994}

Article II(1)(b) of GATT 1994 provides:

The products described in ... the Schedule relating to any contracting party, which are the products of territories of other contracting parties, shall, on their importation into the territory to which the Schedule relates... be exempt from ordinary customs duties in excess of those set forth and provided for therein. Such products shall also be exempt from all other duties or charges of any kind imposed on or in connection with importation in excess of those imposed on the date of this Agreement or those directly and mandatorily required to be imposed thereafter by legislation in force in the importing territory on that date.

Argentina argued that the price band system violated Article II in two ways. First, as noted, the total duties imposed by Chile on products covered by the system had at times exceeded the applicable tariff binding. Each such instance, said Argentina, was a clear violation of sentence one of Article

${ }^{9}$ At one point the applied rate is said to be 7 percent on all products in question, and at another point it is said to be 8 percent. See AB Rep. $\llbracket \llbracket 14,128$.

${ }^{10}$ AB Rep. $\Upsilon 10$. 
II(1)(b) in that it represented the application of "ordinary customs duties" in excess of those set forth in Chile's Schedule of bindings.

Second, Argentina argued that Chile's price band legislation was "mandatory," in the sense that it afforded customs officials no discretion to avoid imposing the requisite duties in cases where the total duty would exceed the binding. Relying on past precedent regarding such mandatory legislation in the GATT and WTO, Argentina then suggested that the mere possibility that such legislation could compel a violation of WTO obligations was enough to condemn it, regardless of whether it had yet been applied in a manner that resulted in a violation.

Chile made a number of arguments in response, most of which were of little avail on their face. But it did have one argument with considerable force - the price band law had been amended to ensure that the total duties applied would never exceed the allowable duty under the binding. Whatever had happened in past practice, and even if the potential for violations under this "mandatory" legislation was evident prior to its amendment, the price band system as amended could no longer result in a violation of the Article II bindings.

\subsubsection{Article 4 of the Agriculture Agreement}

By way of background, one of the principal objectives of the Uruguay Round negotiations was the reduction of barriers to trade in agricultural products. The negotiators undertook to improve the transparency of such barriers as well as to reduce them, and an important part of this process involved the "tariffication" of nontariff barriers, i.e., the conversion of nontariff barriers into conventional tariffs. This process was to be completed by the end of the Round. Nations with substantial nontariff barriers would have the opportunity to convert them into tariffs and schedule them even if the resulting tariffs exceeded their prior tariff bindings under GATT.

Perhaps because it was contemplated that tariffication would be completed during the Round, the Agriculture Agreement does not contain specific text indicating what must be "tariffied" in prospective terms. Instead, Article 4.2 pertaining to "market access" simply provides:

Members shall not maintain, resort to, or revert to any measures of the kind which have been required to be converted into ordinary customs duties, * except as otherwise provided for in Article 5 and Annex 5.

* These measures include quantitative import restrictions, variable import levies, minimum import prices ... and similar border measures other than ordinary customs duties. 
Argentina contended that the price band system was either a "variable import levy" or "minimum import price" within the terms of the footnote, or at least a "similar measure" that had been required to be tariffied. According to this theory, Chile could have availed itself of the opportunity to convert the price band system into an equivalent conventional tariff, and to adjust its binding if necessary before the conclusion of the Uruguay Round. Once the Round ended, however, Chile could no longer "maintain" the price band system, whether or not it had taken the opportunity to tariffy it.

Chile responded in a number of ways. It suggested that the duties associated with the price band system had not been required to be converted into "ordinary customs duties" because they were ordinary customs duties already. Indeed, said Chile, Argentina's argument under Article II of GATT 1994, discussed above, was that the price band system imposed tariffs in excess of the binding on "ordinary customs duties," and thus implicitly conceded that the price band duties fell into that category. Chile argued further that the price band system was not a "variable import levy" or "similar measure," pointing to the conventional characteristics of such measures and to various distinctions between them and the Chilean price band system. Finally, Chile argued that given the vagueness of the footnote to Article 4.2 and its precise coverage, the question of which measures "have been required" to be converted should be answered based on the experience of the WTO membership during the Uruguay Round as to which types of measures had in fact been converted, or had been requested to be converted by other Members. In this regard, Chile noted that price band systems in general had not been converted, and that no Member had asked Chile to convert its price band system on any of the covered products.

\subsection{The Panel decision}

The panel began by rejecting Chile's suggestion that the amendment of the price band system mooted the dispute. Citing precedent, it held that the amendment of a measure should not prevent the dispute process from examining it, and suggested that it could not determine whether the amendment resolved the dispute without first determining how, if at all, the original measure violated WTO law. ${ }^{11}$

${ }^{11}$ Panel Rep. $₫ \uparrow 7.3-7.8$. 


\subsubsection{Analysis under the Agriculture Agreement}

Beginning with Article 4.2 of the Agriculture Agreement, the panel rejected Chile's suggestion that the measures that "have been required" to be converted were limited to those that had actually been converted in practice, or that had been the subject of a request for conversion by another Member state. In so doing, it emphasized that Article 4.2 prohibits Members from maintaining any measures "of the kind which have been required to be converted," and argued that the phrase "of the kind" would have no purpose were the obligation limited to measures that had actually been required to be converted. ${ }^{12}$ Thus, whether or not any nation had asked Chile to convert its price band system and whether or not other price band systems had in fact been converted, the issue for the panel was whether the price band system was among the "measures" covered by the footnote to Article 4.2. ${ }^{13}$

To fall within the footnote, the price band system would have to constitute one of the enumerated devices such as "variable import levies" or "minimum import prices," or at least be among the "similar border measures other than ordinary customs duties." The panel noted that the specifically enumerated devices were not defined in the Agreement. With reference to the footnote as a whole, the panel noted that "all the measures listed there are instruments which are characterized either by a lack of transparency and predictability, or impede the transmission of world prices to the domestic market, or both." 14 It then examined various reports prepared by GATT agriculture committees through the years, and on the basis of those reports set forth the "fundamental characteristics" of variable import levies and "minimum import prices."

The panel concluded that variable levies typically operate on the basis of two prices: a minimum threshold price linked to internal market prices or to a government target price, and a border price for imports usually based on the lowest world market offer price. The variable levy generally equals the difference between the second of these prices and the first. Thus, the variable levy has the quality that when world market prices fall, the variable levy rises. Likewise, variable levies tend to insulate domestic prices from international price variations.

12 Panel Rep. 97.18.

${ }^{13}$ We note that Annex 5 to the Agriculture Agreement affords some exceptions to the tariffication requirements of Article 4.2, but they were not at issue in this case. See AB Rep. $₫ 198$.

14 Panel Rep. $\lceil 7.34$. 
A minimum import price is similar to a variable levy in many respects, except that it usually operates on the basis of the actual transaction price of each import shipment. Whenever that price falls below the import price target, an additional duty is levied equal to the difference. ${ }^{15}$

The panel then noted that the Chilean price band system was not quite the same as either a variable import levy or a minimum import price as it defined them. The price band system did not rely on actual transaction prices like a minimum import price system, but instead on a reference price based on world market prices, a fact that made it more akin to a variable import levy. But unlike traditional variable import levies, the threshold target price was not based on domestic prices or a government target, but on average international prices from preceding years. And neither variable levies nor minimum import prices were generally accompanied by the possibility of a rebate when prices are high. Nevertheless, the panel found that the price band system was "similar" to variable levies and minimum import prices. It insulated the Chilean market from international price fluctuations to a significant extent, imposing a duty that rose as reference prices fell. Likewise, the system was marked by a lack of transparency and predictability regarding the selection of reference prices and markets, and the measurement of movement charges. ${ }^{16}$

It remained to consider the argument that the price band system was not a "similar measure other than ordinary customs duties" - as noted, Chile claimed that the duties under the price band system were indeed "ordinary customs duties." On this point, the panel rejected the suggestion that all duties made subject to an Article II tariff binding were "ordinary." Instead, it concluded that "ordinary" duties are either specific or ad valorem tariffs that depend exclusively on the volume or value of the goods in question and not on other "exogenous factors." The amount of such duties is predictable and transparent in accordance with the objectives of the tariffication process, and in contrast to duties under the price band system. Thus, the price band duties were within the footnote to Article 4.2, and because they did not fit any of the enumerated exceptions, Chile had violated Article 4.2 by maintaining them after the close of the Uruguay Round. ${ }^{17}$

\footnotetext{
${ }^{15}$ Panel Rep. 97.36.

${ }_{17}$ Panel Rep. \\7.38-7.47.

17 Panel Rep. $₫ \uparrow 7.48-7.65$.
} 


\subsubsection{Analysis under Article II of GATT 1994}

On their face, the Article II bindings apply to "ordinary customs duties." In its analysis under the Agriculture Agreement, the panel concluded that the price band duties were not "ordinary customs duties." On the assumption that this phrase has the same meaning in both the Agriculture Agreement and in Article II - a proposition that no one contested - the panel held that the price band duties could not be assessed under the first sentence of Article II(1)(b), which requires that "ordinary customs duties" not exceed the applicable binding.

The second sentence of Article II(1)(b), however, requires that "other duties and charges" not exceed the amounts imposed on the date of the agreement, or thereafter required by mandatory legislation in effect on that date. Further, the Uruguay Round Understanding on the Interpretation of Article II(1)(b) requires that "the nature and level of any 'other duties and charges' levied on bound tariff items ... shall be recorded in the Schedules..." Chile had not listed its price band duties among the "other duties or charges" in its WTO tariff schedules, and on this basis the panel found that the price band system was a violation of Article II(1)(b), second sentence. ${ }^{18}$ It is noteworthy that this argument had not been advanced by Argentina, which instead rested its Article II claim on the proposition that the price band system, prior to its amendment, could result in total duties in excess of Chile's bindings.

\subsection{The Appellate Body decision}

The Appellate Body addressed some procedural points that we note only in passing. It held that the amendment of the price band system during the course of the dispute did not preclude the panel from considering it, and further concluded that the panel could evaluate the price band system as amended as well as in its original form because the amendment did not change the "essence" of the system. ${ }^{19}$ This principle allows the dispute process to proceed in the face of amendments or other changes to a challenged scheme without the need for a new round of consultations, request for panel, and so on. It thus allows dispute resolution to proceed more quickly and avoids the possibility of strategic behavior that could delay it, a policy which strikes us as quite sensible.

18 Panel Rep. $₫$ \7.104-7.108.

19 AB Rep. ๆণ134-144. 
The Appellate Body also spent considerable time on the proper "order of analysis" in the case - whether the panel should have addressed the Agriculture Agreement first or the Article II issue first. It ultimately approved of the panel's decision to consider the Agriculture Agreement first on the ground that its provisions more "specifically" addressed the dispute. Chile apparently believed that had the Article II issue been considered first, the panel might have ruled that the price band system imposed "ordinary customs duties," and was thus outside the footnote to Article 4.2 of the Agriculture Agreement. The Appellate Body saw no merit in this contention, however, noting that the two provisions create separate and distinct obligations and that the outcome of the dispute would be the same regardless of the order of analysis. ${ }^{20}$ As the issue seems quite unimportant for this reason, we do not address it further.

\subsubsection{Analysis of the Agriculture Agreement}

The Appellate Body began by considering Chile's argument, rejected below, that the reference in Article 4.2 to measures that "have been required" to be converted limits the obligation to measures that were in fact converted or had been requested to be converted. The Appellate Body agreed with the panel that the use of the present perfect tense refers to the obligation to convert measures at the conclusion of the Uruguay Round the phrase "have been required" merely refers back to the point in time when the obligation arose, and does not limit the scope of the obligation to measures that were actually converted or discussed. It further emphasized that the footnote to Article 4.2 contains an illustrative and not exhaustive list of measures, thus suggesting that not all measures covered by the obligation had been specifically identified by the end of the Round.

It then proceeded to review the question whether the price band system was among the enumerated "measures" in the footnote, or at least "similar" to them. It quibbled with the panel's notion of similarity, which had rested on the proposition that measures should share some "fundamental characteristics." The Appellate Body thought that such a test unnecessarily embroiled the decisionmaker in assessing what is "fundamental" and what is not, and preferred merely to search for "likeness or resemblance sufficient to be similar." ${ }^{21}$ It also quibbled with the panel's resort to extrinsic materials, such as the reports of old GATT agricultural

20 AB Rep. $₫$ \178-191.

21 AB Rep. $\$ 226$. 
committees, for the purpose of defining the concepts of "variable import levy" and "minimum import price," preferring instead to rely on the ordinary meaning of the words in their treaty context and in light of their object and purpose, the familiar approach to treaty interpretation under the Vienna Convention. ${ }^{22}$

Following this approach, it found that a "variable levy" was a measure whereunder the amount of the duty was variable, and the variability was attributable to the terms of the measure itself (to differentiate it from an ordinary tariff, which could vary over time due to legislative amendment). In addition, a variable levy had to be at odds with the "object and purpose" of Article 4, which meant that it must lack the "transparency and predictability" of ordinary customs duties. ${ }^{23}$ As to the concept of "minimum import price," the Appellate Body accepted the panel's definition in terms of a target threshold price and a levy that was based on the difference between the actual transaction price and the target price.

Having defined the terms in the footnote, the Appellate Body proceeded to the question of "similarity." Chile again emphasized the differences between traditional variable levies as described by the panel, but the Appellate Body was unpersuaded. It found that Chile's system could still have had the effect of insulating domestic prices from international price movements. Further, many aspects of the system such as the selection of reference prices and the addition of movement charges to construct the price band - were not transparent and produced unpredictable results. ${ }^{24}$

Chile contended that the amendment to the law, which capped duties in accordance with the Article II binding, distinguished the price band system from the "measures" that had been required to be converted. But the Appellate Body found that the amendment to the law did not alter the essential nature of the price band measure, its trade distorting effects, or its lack of transparency and predictability. ${ }^{25}$ The Appellate Body made note of the fact that the reference price in the Chilean system was chosen in such a way that it might "overcompensate" for downward price fluctuations in international markets, ${ }^{26}$ and also noted that the failure to add movement expenses to the reference price tended to inflate the

\footnotetext{
AB Rep. $₫ \Upsilon 230-231$.

AB Rep. $\mid 234$.

AB Rep. $\S 246$.

AB Rep. $\llbracket \llbracket 254-262$.

${ }^{26}$ AB Rep. $\mid 260$.
} 
amount of the duty, ${ }^{27}$ without explaining clearly why these facts were important. The Appellate Body further argued that if the presence of a cap on measures such as variable levies was enough to insulate them from the obligations of Article 4.2, there would have been no need to require conversion of any measure - the negotiators could simply have required that all agricultural tariffs be bound. ${ }^{28}$

Finally, the Appellate Body turned to the way that the panel had defined "ordinary customs duties" as duties that depend only on the value or volume of the goods and not on other "exogenous factors." It noted that nations may well choose to set their "ordinary" duties based in part on "exogenous" considerations, and that the text of Article II is quite unclear as to what constitutes an "ordinary" duty or "other duties or charges." The fact that most Member duties in most tariff schedules are simple ad valorem or specific duties is not relevant as to what is "ordinary" in the language of the treaty - Member state practice is only relevant if it is "subsequent practice" under the Vienna Convention, and the panel had provided no support for the conclusion here. ${ }^{29}$ The Appellate Body accordingly reversed the panel in so far as it had defined "ordinary" duties as duties that did not depend on "exogenous" factors. But that did not change the fact that the price band system was "similar" to variable import levies and minimum import prices, and thus a violation of Article 4.2.

\subsubsection{Analysis under Article II of GATT 1994}

Chile argued on appeal that the panel erred when it found an inconsistency between the price band measure and Article II(1)(b), second sentence, because Argentina had not made such an argument during the course of the panel proceedings. The Appellate Body concurred. Although Argentina's request for a panel was phrased broadly enough to cover all aspects of Article II, the fact that Argentina did not subsequently advance the particular claim that the panel embraced meant that the panel had gone beyond an "assessment of the matter before it" under Article 11 of the DSU. To do so deprived Chile of "due process," as it was not on notice of the need to present a defense as to the consistency of the price band system with Article II(1)(b), second sentence. ${ }^{30}$

\footnotetext{
27 AB Rep. 9250.

28 AB Rep. $\$ 256$.

29 AB Rep. $\$ 273$.

30 AB Rep. ๆ $145-177$.
} 
The Appellate Body thus overruled the finding against Chile under Article II(1)(b), second sentence, because the issue was not properly before the panel. Because it had also overruled the panel on the definition of "ordinary customs duties," it left open the issue whether the price band system created "ordinary customs duties" or "other duties or charges" for purposes of Article II. As it had already affirmed the finding that the price band system violated Article 4.2 of the Agriculture Agreement, the Appellate Body found no need to address its consistency with Article II(1)(b), first sentence.

\section{Critical Analysis}

\subsection{Legal commentary}

\subsubsection{The Agriculture Agreement}

Article 4.2 is an odd provision in many respects, and there is certainly some force to the position put forward by Chile. As indicated, Article 4.2 states that Members shall not "maintain, resort to or revert to" any measures that "have been required to be converted into ordinary customs duties," and lists some examples of such measures in the footnote. But nowhere in the Agriculture Agreement or in any other treaty text can one find a complete listing of measures which "have been required" to be converted, and no text contains any general criteria for the identification of such measures. The panel and the Appellate Body are no doubt right that many of the illustrative measures lack transparency and predictability, but those criteria are not to be found in the text either.

In the face of a text that refers to measures that "have been required" to be converted, but that lacks any comprehensive listing of them or any general criteria for identifying them, Chile's suggestion that the phrase refers back to a shared understanding among WTO members developed during the Uruguay Round has considerable plausibility. On this reading, the measures that "have been required" to be converted would be the sorts of measures actually converted as a result of Uruguay Round negotiations. Members could not maintain or revert to measures of that "kind," but could maintain other measures of a kind that had not been converted. The fact that a number of nations had price band systems, that apparently none were converted, and that no nation was asked to convert a price band system, then offers considerable evidence that price bands were considered to be different from the measures that were converted, and that they had not been "required" to be converted. The Appellate Body's 
observation that the footnote is illustrative and not exhaustive is of little moment on this view, as it merely lists some examples of measures that were in fact converted and was not intended to impose obligations with respect to other measures. To be sure, such a reading of Article 4.2 would leave open the question of what sort of measures are of the "kind" that had been converted, but shared practice would at least provide a clearer guide as to the types of measures that the negotiators had in mind.

We do not mean to say that the panel and Appellate Body were necessarily wrong in their legal disposition of the matter, ${ }^{31}$ but we do think it somewhat peculiar that WTO Members should have structured a binding obligation in such a loose way as the case imagines - a nonexhaustive list of covered measures with no written set of unifying criteria, coupled with a rather open-ended "similarity" inquiry to determine what other types of measures were condemned. Such an approach is doubly peculiar in that the opportunity to convert to "ordinary customs duties" was lost as soon as the Uruguay Round ended. Members would thus have been forced at the end of the Round to guess what measures were covered and to convert all of those that might be covered lest they be lost and replaced with nothing.

Perhaps further reinforcing Chile's view is the fact that both parties to the dispute apparently thought that the duties under the price band system were covered by the Article II bindings, which by their terms apply only to "ordinary customs duties." That is why Argentina originally framed a claim under Article II(1)(b), sentence one, and ignored sentence two. But as Chile argued, if the price band system yielded "ordinary customs duties" subject to the binding, then what is meant by a requirement that they be converted into ordinary customs duties?

Lastly, we note the obvious difficulties inherent in "converting" the price band system into conventional tariffs. Conventional tariffs would not have the moderating effect on price fluctuations of the price band system, and to the extent that such moderation was a goal of the Chilean system it could not be achieved using conventional duties. A conventional tariff does not rise when international prices fall, or generate a rebate

31 Indeed, we take note of a NAFTA decision in which the position of the parties accords with that of Argentina in this case - in the course of a dispute over Canadian tariff changes, both Canada and the United States apparently agreed that Article 4.2 required the tariffication of all non-tariff measures (save those protected by Annex 5). See In the Matter of Tariffs Applied by Canada to Certain U.S.-Origin Agricultural Products, Panel No. CDA-95-2008-01, 1996 FTAPD LEXIS 10 (1996). 
when they are high. Moreover, it is hardly clear how one would have determined the conventional "tariff equivalent" of the price band system (though, to be sure, the same issue would have arisen for some of the other "measures" clearly covered by the footnote to Article 4.2).

In sum, we see considerable basis to think that Chile's interpretation of the system is a plausible one, though we hesitate to say which interpretation is right. Article 4.2 is no model of clarity, and it comes as little surprise that it should be subject to controversy.

Given the Appellate Body's approach to the question of "similarity," the case also leaves open a number of issues for the future. Are all price band systems "similar," or do some remain permissible? What of other conceivable mechanisms involving border measures to stabilize domestic agricultural prices? Are seasonal tariffs distinguishable because of a lesser degree of similarity to variable levies and minimum import prices? How crucial to the finding of "similarity" were the various factors that tended to inflate the duty under Chile's system, along with its non-transparency and unpredictability?

\subsubsection{Article II}

We have no quarrel with the principle that a panel should not rule sua sponte on matters that neither party has raised, for as the Appellate Body indicated, basic issues of fairness and due process are implicated when a party loses on grounds that it was not given an opportunity to address. The decision to reverse the panel finding against Chile under Article II(1)(b), second sentence, thus seems the right one.

But the Appellate Body also avoided the issue under Article II(1)(b), first sentence, even though it seemed to endorse the proposition that "ordinary customs duties" has the same meaning in both Article II and the Agriculture Agreement. By holding that the price band system had been required to be converted into ordinary customs duties, the immediate implication is that the duties under the price band system are not ordinary customs duties. If that is right, then the panel's conclusion that the duties are outside the purview of Article II(1)(b), sentence one, would seem to follow inexorably. But because the Appellate Body ducked the matter, the question whether a measure such as a price band system is subject to the bindings of sentence one or to the scheduling obligation of sentence two, and the broader question of what constitutes an "ordinary customs duty," remain quite muddled. This last question obviously has potential implications that extend beyond the agricultural sector, although we are not in a position to assess its significance in other areas. 


\subsection{Economic commentary}

From an economic point of view, the wisdom of the ruling that (some? all?) price band systems must be replaced with ordinary tariffs is rather difficult to assess because it turns on competing factors. We first identify these factors, and then summarize their implications.

\subsubsection{Factor one: the benefits of tariffication}

The tariffication process envisioned by the Agriculture Agreement facilitates the negotiation between governments of mutually beneficial and reciprocal reductions in trade barriers. To develop this point, we identify two prominent reasons that governments may impose import barriers, and their implications for the role of reciprocal trade agreements in world trade. ${ }^{32}$ With this foundation in place, we next make the argument that tariffication can facilitate mutually beneficial and reciprocal tradeliberalization negotiations between governments.

We focus first on a political rationale for import barriers. To isolate this rationale, we consider the situation in which a government presides over a small country. As is well known, if such a government were to maximize the national income of its country, then its optimal unilateral trade policy would be free trade. Suppose, though, that the government is motivated by political considerations as well. In particular, as suggested by the theory of public choice, the government may be more sensitive to the impact of trade liberalization on import-competing industries than on consumers. The underlying idea is straightforward: import-competing industries are harmed by lower import prices and may be better organized and more politically efficacious than consumers, who are the beneficiaries of lower import prices. The government may therefore wish to impose import barriers. Accordingly, the government would then regard a reduction in import barriers as costly, and such a "concession" would be entertained only if it could be exchanged for some benefit that is offered by another nation.

This rationale on its own, however, does not give rise to an explanation for why governments seek reciprocal trade negotiations. If all countries are small with governments that use import barriers for political reasons, then no one government can adjust its trade policy and thereby confer a

${ }^{32}$ For further discussion of the theory of reciprocal trade agreements, see Chapter 2 of Kyle Bagwell and Robert W. Staiger, The Economics of the World Trading System, 2002, The MIT Press: Cambridge, MA. 
benefit to another. For example, if the government of country A considers the proposal that it incur the cost of a reduction in its own tariff in exchange for the benefit of a tariff reduction by country $B$, then the government will reject this proposal as being one that has real costs but no benefits. This is because the trade policy of a small country (country B) does not change world prices and therefore does not offer any benefit to exporters in another country (country A). ${ }^{33}$

The second rationale is economic in nature and derives from the possibility that the country may be large. To isolate this case, suppose that the government of a large country seeks to maximize national income. When the government of a large country imposes an import barrier, some of the cost of the barrier is borne by foreign exporters, who sell at a lower export price (i.e., lose access to the domestic market). Thus, if the government of a large country imposes an import barrier, then domestic import-competing firms win, domestic consumers lose, and foreign exporters lose. The loss experienced by foreign exporters is an international externality that is associated with the government's trade policy. Since the government does not internalize the costs of import barriers on foreign exporters, the optimal unilateral trade policy is not free trade but rather entails import barriers (e.g., positive import tariffs). In effect, with import barriers, the government shifts onto foreign exporters some of the costs of helping its import-competing firms.

This rationale has the added benefit of suggesting a theory of reciprocal trade agreements. Suppose that countries A and B are both large with governments that maximize national income. When the government of country A reduces an import barrier below the optimal unilateral level, it incurs a cost, and it is therefore willing to make such a concession only if it expects a sufficient benefit from a reciprocal reduction in an import barrier by the government of country B. Given that country B is large, this expectation is now entirely rational: when the government of country $B$ reduces an import barrier, the exporters in country A absorb some of the benefit since they sell at a higher export price (i.e., gain access to

${ }^{33}$ While the small-country assumption serves as a useful benchmark, it is not clear that many countries are, in fact, small. It is possible that a country is small in some markets but not others, and likewise a country may be larger with respect to some countries (e.g., neighboring countries) than others. Further, even if it is posited that several countries are (approximately) small, if such countries all cut tariffs as part of a multilateral agreement, then the combined impact of their tariff cuts could change world prices. 
country B's market). Thus, while each government has a unilateral incentive to impose import barriers, the governments together have a collective incentive to negotiate a trade agreement in which these barriers are reduced in a reciprocal manner.

The two rationales may be usefully joined. If countries are large with governments that have economic and also political motivations, then, as the discussion above suggests, the unilateral trade policies of governments result in import barriers. Furthermore, given that an import barrier imposed by the government of any one country generates a negative international externality to the (political-economic) welfare of the government of its trading partner, the governments can negotiate mutually beneficial and reciprocal reductions in trade barriers.

We emphasize that this perspective does not require that governments possess a sophisticated understanding of the external ("terms-of-trade") effects of their respective trade policies, or that governments acting in isolation actually seek to raise national income through "optimal tariff" policies. Indeed, governments may have political motivations when imposing tariffs, and may evaluate prospective trade agreements from a political orientation as well, balancing the political cost of a reduction in support from import-competing interests against the political benefit of an increase in support from export interests. The important point is that such an orientation reflects a belief on the part of each government that a reduction in a trading partner's tariff would generate some external benefit to domestic exporters. If pressed, government officials may offer the specific explanation that the external benefit derives from the improved access that exporters would then have to the trading partner's market. From an economic perspective, however, this is just another way of saying that a reduction in a trading partner's tariff results in an increase in the price at which domestic exporters sell. This is precisely the international externality that underlies the theoretical foundation presented above.

Our discussion here suggests that the trade-policy relationship between governments has the characteristic of a Prisoners' Dilemma game: the governments recognize that they are each better off when they both liberalize than when they both impose import barriers, but liberalization is difficult to maintain since each government does better yet if it alone "cheats" and imposes import barriers. In light of this characterization, it is clear that a trade agreement must have adequate enforcement provisions, so as to dissuade any one government from cheating on an agreement to liberalize. The threat of retaliation is the natural means of enforcing a 
trade agreement. A patient government will not pursue the short-term benefit from cheating, if it recognizes that such behavior gives rise to a long-term cost that is associated with retaliation (e.g., a return to unilateral policies).

With this context in place, we now discuss how tariffication facilitates the negotiation between governments of mutually beneficial and reciprocal reductions in trade barriers. The tariffication process has four important, and related, benefits. It lowers the transactions costs of reciprocal trade negotiations, it increases the expected trade volume resulting from tariff concessions, it reduces the uncertainty about trade volumes following a trade agreement, and it makes easier the enforcement of a trade agreement.

The greater the number of protectionist policy instruments that affect trade in a given product, the more difficult (and costly) it is to evaluate a particular concession on exports of that product. It is much harder to estimate the gains in market access opportunities for a reduction in a foreign tariff, for example, if exports subject to the lower tariff would also be subject to quotas, discriminatory domestic regulations, and other sorts of protective measures. And if trade negotiators face greater costs in the evaluation of offers by other nations, it is likely that fewer deals will be finalized in a given negotiating window.

Similarly, if a number of protectionist policy instruments can affect exports of a particular product, it becomes harder to have a high degree of confidence about the increased trade volume that will result from a concession on a particular instrument. Negotiators must worry that the apparent benefits of a tariff concession, for example, will be wiped out by unexpected consequences of some other protectionist instrument. Such possibilities reduce the expected increase in trade volume associated with concessions on tariffs or any other policy instrument and make them less valuable.

A further point is that not all protectionist instruments are equally predictable as to their effects on trade volume. A conventional tariff is generally thought to have relatively more predictable effects than a quota, for example. With a tariff, exporters know exactly how much "tax" they must pay to enter a given market. They will still face uncertainty about that market due to the usual factors that affect market demand and supply, but at least the amount of protection is certain. By contrast, under a quota, exporters must worry that other supplier(s) will have the opportunity to fill the quota before them, or that the importing nation will allocate the quota in a way that disadvantages them. These uncertainties 
are added to the usual demand and supply uncertainties. When trade negotiators are averse to risk associated with the volume of trade under a trade agreement, they will offer less to secure a given expected volume of trade if the uncertainty about the volume of trade is greater.

Finally, if trade-policy instruments are non-transparent, then the enforcement of trade agreements is particularly difficult. Our discussion above emphasizes that trade-policy interactions between governments share characteristics with the Prisoners' Dilemma game. Each government makes a costly concession in order to enjoy the benefits of a reciprocal concession by the other. If governments' trade policies were difficult to observe, then each government would be tempted to (secretly) withdraw its concession. Cheating of this kind can undermine a mutually beneficial trade agreement between governments. Tariffication thus facilitates such agreements, since tariffs are transparent and cheating is accordingly more difficult.

For these reasons, it is in the mutual interest of parties to reciprocal trade negotiations to limit the number of protectionist instruments in play as much as possible, and to channel protection into instruments that produce the least uncertainty about trading volume and the least opportunity for cheating. Tariffs are generally regarded as relatively transparent and predictable, and so they are the natural choice as the favored protectionist instrument. These observations go far toward explaining some basic structural features of the original GATT - the fact that negotiations were focused on tariffs and the Article II bindings, the presence of a general prohibition on quantitative restrictions in Article XI, and the prohibition on discriminatory domestic regulations and taxes in Article III.

The tariffication process under the Agriculture Agreement follows the same logic. The agricultural sector, certainly more so than most, had seen a proliferation of trade barriers beyond conventional tariffs. These barriers often resulted from the prevalence of agricultural price support and stabilization policies, and the need to insulate domestic markets from foreign price fluctuations if domestic targets were to be achieved. The proliferation of these barriers - the quantitative restrictions, variable levies, minimum import price systems, and the like - complicated market access negotiations in agriculture because they made it difficult to evaluate conventional tariff concessions, lessened the expected benefits of concessions on other policy instruments, increased the uncertainty associated with agricultural trade, and made enforcement more difficult. Tariffication addressed all of these problems. 


\subsubsection{Factor two: the effect of a tariffication requirement on the average tariff level}

If Chile's price band system was truly problematic, why did Chile's trading partners not complain about it or raise the issue of tariffication explicitly during the Uruguay Round? Why, for that matter, did other nations with price band systems not tariffy their price bands or have discussions about the matter? We can only speculate as to the answer, but it is possible that tariffication may have resulted in higher average protection, and this prospect may have led trading partners to prefer that price bands remain in place.

The logic here is straightforward. One effect of the price band system was to reduce the variability of Chile's internal prices by insulating them from international price fluctuations outside of the price band. The rationale for such a system may lie in the fact that Chile's agricultural producers care not only about the average price that they receive, but about its volatility - i.e., that they are risk averse and to some degree will sacrifice periods of high prices to avoid periods of low prices.

If that is correct, then agricultural producers will be happy to trade off some reduction in average prices received to reduce uncertainty about price. And if political opposition exists to higher agricultural prices, the resulting political equilibrium may well entail some sort of device to reduce volatility, for which agricultural producers will "pay" in the form of lower average prices. One way to see the point is to imagine two different protectionist regimes - one with a fixed conventional tariff, and one with a price band. Let the two regimes be designed so that agricultural producers are indifferent between them. Thus, assuming risk aversion on the part of the agricultural producers, the price band system will produce lower prices on average. The domestic opponents of high agricultural prices will likely prefer the price band option for that reason, even if they are indifferent to price volatility themselves. Put differently, a price band system - with its reduced price volatility - may be Pareto optimal from a domestic political standpoint.

If the government is subsequently prohibited from maintaining a price band system and forced to substitute a conventional fixed tariff, the new domestic political equilibrium will likely involve a higher tariff on average. Intuitively, as agricultural producers are confronted with the prospect of greater price variability, their demand for protection will intensify. Assuming that domestic opponents of high agricultural prices are not themselves significantly harmed by greater price variability, the 
domestic political process might be expected to achieve a new equilibrium in which the fixed tariff is positioned above the average tariff under the price band system.

If we are right to this point, then it is conceivable that trading partners would prefer to allow the price band system to persist rather than to be "tariffied," despite its disadvantages as noted earlier. Tariffication would raise the average degree of protection that they confront on their exports, and as a consequence tariffication would contribute to a lower expected export price (i.e., lower expected market access). But we also note that the price band system may amplify (exogenous) fluctuations in the prices that exporters receive. ${ }^{34}$ For example, when the export (i.e., world) price for a product is low, the price band system may call for a higher tariff, which works to further depress the export price. The rebate under the price band system when prices are high also tends to increase the net price received by foreign sellers. Tariffication may thus diminish the variability of the price at which exporters sell. An argument that trading partners are hurt by tariffication thus turns on the proposition that the cost to exporters of any associated decrease in the average export price outweighs the benefit of any associated reduction in the variability of export prices. This is more likely to hold if Chilean import-competing firms are more risk averse than are foreign exporters.

\subsubsection{Summary of implications}

Our discussion in the preceding subsection raises the possibility that trading partners may be better off with the price band than without it. This possibility seems even more plausible when, as with the amended Chilean system, the importing nation makes clear that it will never exceed its Article II binding. Recall that Chile had bound its tariffs at 31.5 percent, but its applied ad valorem duty was only 7-8 percent. Even with the price band system, the total duty was usually less than 31.5 percent, and could never be higher after the law was amended. It seems somewhat odd to condemn Chile under these circumstances when it had the right to impose a fixed 31.5 percent tariff if it wished, and it is difficult to imagine that the lack of "transparency and predictability" in the price band system could have done more to limit trade than a fixed tariff set at the level of the binding. Indeed, regardless of risk preferences, foreign

${ }^{34}$ A related point is recognized in the literature on variable import levies. For a recent contribution, see H. Nordstrom, "Do Variable Levies Beggar Thy Neighbor?," European Journal of Political Economy, 2001, 17, 2: 420-430. 
exporters are better off facing tariffs that are variable over some range than a tariff that is fixed and set equal to the top value (i.e., the binding) of that range.

We are cognizant of the fact that, to some extent, this argument proves too much. First, if we are right that the level of trade protection will be less on average if the price band system is allowed to remain in place, why did Argentina bring a case? It must have expected to gain from the proceeding. It is possible to speculate. Perhaps Argentine exporters are risk averse and expected that Chile would set a fixed tariff sufficiently below its binding to leave them better off, or perhaps Argentina expected to extract some settlement by filing a strategic suit. A further possibility is that Argentina objected to the design of this particular price band system perhaps its linkage between the tariff and the date of shipment, or its general lack of transparency, effectively facilitated the application of discriminatory tariffs that disproportionately burdened Argentina. It is also possible that Argentina was motivated to challenge the law before its amendment clarified that the tariff would never exceed the binding, and for some reason felt obliged to continue the case even after the amendment was passed. But we do not know the answer to this question.

Second, the Chilean price band system is similar to classic variable levies, which were tariffied in at least some cases during the Uruguay Round. If devices for reducing price volatility were on balance useful to the trading system because they facilitated a reduction in the average level of protection, why were any of these devices made subject to tariffication? In thinking about this question, it is useful to distinguish between transparent and non-transparent devices. Following our discussion above on the benefits of tariffication, it may be argued that non-transparent devices impede effective negotiations. Tariffication of such devices may thus facilitate mutually beneficial trade liberalization. Is the Chilean price band system "non-transparent?" Again, it is useful to contrast this system with a transparent tariff that is set at the binding. As long as it can be verified that the import tariffs called for under the price band system do not exceed the binding, the system is transparent in the sense that it can be verified that the negotiated binding is not violated. From this perspective, a price band system that is capped at the negotiated binding captures the main benefits of tariffication while also providing trading partners with frequent "gifts" of import tariffs that are strictly below the binding. We may thus endorse the tariffication of non-transparent measures generally, yet still wonder about the wisdom of tariffying a price band system that includes a cap to ensure that the tariff binding is never exceeded. 


\section{Conclusion}

The Chilean price band system raised a difficult case from a legal perspective, and an intriguing set of issues from an economic perspective. On the legal side, Chile's position had some appealing elements. No WTO Member had asked Chile to tariffy its price band system during the Uruguay Round, and other members had apparently retained their own price band systems. The lack of clear criteria in the Agriculture Agreement for determining which measures should be tariffied further buffered Chile's suggestion that shared understanding during the negotiation process should be the touchstone. Once Chile amended the system to ensure that total tariffs never exceeded its binding, it apparently brought itself into full compliance with what it fairly understood to be its obligations under the Agreement.

Argentina's position also had its strengths. The price band system surely bore considerable resemblance to enumerated measures in Article 4 of the Agriculture Agreement that were tariffied, and it is thus reasonable to deem it "similar." Chile's system also lacked transparency in many respects, and no doubt frustrated trading partners who were unable to predict the variable levy with confidence.

Accordingly, it seems to us that the dispute could plausibly have been resolved either way. It is difficult to say which resolution is the "right" one as a legal matter.

From an economic perspective, the case is also a hard one. We cannot confidently say whether the demise of Chile's price band system will be trade liberalizing or trade restricting. It will be most interesting to see what fixed tariff rate Chile sets when it eliminates the price band. It would be an interesting though no doubt challenging exercise to compare it with the average total tariffs during the price band system to see which is higher, and to compare trading volumes before and after to see if access to Chile's market has been enhanced or diminished.

\section{References}

Bagwell, Kyle and Robert W. Staiger (2002). The Economics of the World Trading System (MIT Press: Cambridge MA).

Nordstrom, H. (2001). Do Variable Levies Beggar Thy Neighbor?, European Journal of Political Economy 17: 420-430. 